長谷川 真二
川 松 隈 英 樹 松 尾 哲 高 橋 稔
土田 弘 基**
船橋二和病院内科 同泌尿器科* 国立佐倉病院内科**

ey words：悪性症候群，横紋筋融解症，メトクロプラミド，慢性腎不全

〈要旨〉

今回我々は維持透析患者に悪性症候群が合併した稀な 1 例を経験したので報告する.

䌅尿病性腎症により維持血液透析中の 42 歳男性が, 高熱と, 眼振, 手足の振戦, 幻覚幻聴により入院した。血液検 sの結果, GOT $459 \mathrm{IU} / l$, LDH 1,669 IU/l, CPK $529 \mathrm{lU} / l$, aldolase $13.3 \mathrm{mU} / \mathrm{ml}$, myoglobin 3,200 ng/m $l$ と異常 認め, 著明な低酸素血症 $\left(\mathrm{PO}_{2} 27.1 \mathrm{mmHg}, \mathrm{PCO}_{2} 42.8 \mathrm{mmHg}\right)$ を合併していた。患者は, 制吐剂として頻用され 塩酸メトクロプラミド (metoclopramide hydrochloride : $30 \mathrm{mg} /$ 日) を 5 か月間内服していた。また発熱，自律神 症状・錐体外路症状・意識障害の症状より悪性症候群（syndrome malin）と診断した。

このため薬物の中止と臨時に血液透析を行い症状は改善し, 良好な経過を示した。

\title{
case of syndrome malin induced by metoclopramide during maintenance emodialysis
}

hinji Hasegawa, Hideki Matsukuma, Akira Matsuo, Minoru Takahashi, Minoru Kawamura*, Hiroki suchida**

Eepartment of Internal Medicine and Urology*, Funabashi Futawa Hospital ; Department of Internal Medicine Sækura Hospital**

We report a rare case of a patient who developed syndrome malin (SM) during maintenance hemodialysis.

i 42-year-old man, for whom maintenance hemodialysis was being been performed for diabetic nephropathy, was admitted to the hospital because of high fever, nystagums, tremor and hallucinations. On the blood examinaivn, the GOT was $459 \mathrm{lU} / l$, LDH 1,669 IU/l, CPK $529 \mathrm{lU} / l$, aldolase $13.3 \mathrm{mU} / \mathrm{ml}$, myoglobin 3,200 $\mathrm{ng} / \mathrm{ml}$, and an arterial blood gas examination revealed severe hypoxemia $\left(\mathrm{PO}_{2} 27.1 \mathrm{mmHg}, \mathrm{PCO}_{2} 42.8 \mathrm{mmHg}\right)$. At that time to had been prescribed metoclopramide hydrocloride $(30 \mathrm{mg} /$ day) orally, which is often used for the control of neusea, for five months. The symptoms of hyperthermia, autonomic instability, extrapyramidal signs and altered cnsciousness were consistent with a diagnosis of syndrome malin.

Accordingly we withdrew the metoclopramide and performed extrahemodialysis therapy. The symptoms then ridly improved and the patient made a rapid recovery.

猜言

惡性症候群 (syndrome malin) は, 抗精神病薬内服中 證熱とともに多彩な自律神経症状・振戦等の錐体外路 症状・意識障害を呈する重篤な合併症であり，死亡率が 高く予後は不良である。

今回我々は，制吐剤として頻用される塩酸メトクロプ ラミド (metoclopramide hydrochloride) 内服中に悪性 症候群を合併した維持透析患者の 1 例を経験したので若
干の考察を加えて報告する。

症例

患者：42 歳, 男性.

主訴：発熱, 意識障害, 振戦。

既往歴: 39 歳糖尿病 (IDDM) と診断され, Insulin 療 法を開始する. 39 歳糖尿病性腎症, 糖尿病性網膜症の進 行を認めた。 88 年 12 月, 41 歳で腎不全のため血液透析 に導入された。 89 年 6 月糖尿病性胃腸障害のため塩酸メ

長谷川真二 船橋二和病院内科 $\quad$ T 274 船橋市二和東 5-1-1 (0474-48-7111) 
表 1 Laboratory data on admission (November, 1989)

\begin{tabular}{|c|c|c|c|c|c|c|c|}
\hline \multicolumn{2}{|c|}{ Peripheral blood } & TP & $6.8 \mathrm{~g} / \mathrm{d} l$ & $\mathrm{Na}$ & $137 \mathrm{mEq} / l$ & \multicolumn{2}{|c|}{ Arterial blood gas } \\
\hline WBC & $8,900 / \mu l$ & Alb & $4.0 \mathrm{~g} / \mathrm{d} l_{1}$ & $\mathrm{~K}$ & $3.6 \mathrm{mEq} / l$ & PH & 7.322 \\
\hline $\mathrm{RBC}$ & $246 \times 10^{4} / \mu l$ & T-Bil & $0.3 \mathrm{mg} / \mathrm{d} l$ & $\mathrm{Cl}$ & $98 \mathrm{mEq} / l$ & $\mathrm{PCO}_{2}$ & $42.8 \mathrm{mmHg}$ \\
\hline $\mathrm{Hb}$ & $6.5 \mathrm{~g} / \mathrm{d} l$ & $\mathrm{Al}-\mathrm{P}$ & $1,221 \mathrm{IU} / l$ & $\beta_{2}-\mathrm{MG}$ & $32 \mathrm{mg} / l$ & $\mathrm{PO}_{2}$ & $27.1 \mathrm{mmHg}$ \\
\hline $\mathrm{Ht}$ & $21.9 \%$ & GOT & $459 \mathrm{IU} / l$ & & & $\mathrm{HCO}_{3}$ & $22.1 \mathrm{mmol} / \mathrm{l}$ \\
\hline \multirow[t]{2}{*}{ PLC } & $33.8 \times 10^{4} / \mu l$ & GPT & $357 \mathrm{IU} / l$ & Urinalysis & & $\mathrm{BE}$ & $-3.0 \mathrm{mmol} / \mathrm{l}$ \\
\hline & & $\mathrm{LDH}$ & $1,661 \mathrm{IU} / l$ & $\mathrm{PH}$ & 6 & $\mathrm{O}_{2} \mathrm{SAT}$ & $45.5 \%$ \\
\hline \multicolumn{2}{|c|}{ Blood chemistry } & CPK & $529 \mathrm{IU} / l$ & US & $2+$ & & \\
\hline CRP & $14.4 \mathrm{mg} / \mathrm{d} l$ & T-Chol & $109 \mathrm{mg} / \mathrm{d} l$ & UP & + & & \\
\hline ESR & $24 \mathrm{~mm} / 1 \mathrm{~h}$ & TG & $96 \mathrm{mg} / \mathrm{d} l$ & URO & \pm & & \\
\hline HBsAg & $(-)$ & UN & $22.5 \mathrm{mg} / \mathrm{d} l$ & $\mathrm{RBC}$ & $0 / \mathrm{hpf}$ & & \\
\hline FPG & $198 \mathrm{mg} / \mathrm{d} l$ & $\mathrm{Cr}$ & $5.3 \mathrm{mg} / \mathrm{d} l$ & WBC & $1-2 / \mathrm{hpf}$ & & \\
\hline
\end{tabular}

トクロプラミドを 1 日 $30 \mathrm{mg}$ 内服しはじめた。. 8 月一過 性に手の振戦，9月自発性が低下し，不眠を訴えた。

現病歴：11月 5 日悪寒とともに $39^{\circ} \mathrm{C}$ 発熱があり,翌 6 日血液透析終了時には一旦解熱した。しかし夜間より 再び発熱し，7日 $41^{\circ} \mathrm{C}$ 高熱になり，8日透析時に高血 糖 $(927 \mathrm{mg} / \mathrm{d} l)$ を認め, 著明な発汗, 眼振, 四肢振戦, 幻覚・幻聴が出現し，独り言を発し，意識混濁を認めた。 透析終了時には解熱し, 血糖も低下し, 意識状態も改善 する.9日症状は改善したが, 翌 10 日再び不穏状態にな り，血液ガスにて低酸素血症 $\left(\mathrm{PO}_{2} 27.1 \mathrm{mmHg}\right)$ を認め, 当院入院となった。

入院時現症：意識軽度混濁，血圧 $160 / 80$, 脈拍 82 / 分 整, 顔面無欲様顔貌, 発汗著明, 甲状腺腫なし, リンパ 節腫脹なし, 心音正常, 心雑音なし, 肺野清明, 肝脾腎 触知せず，血管雑音なし，軽度浮腫，四肢振戦を認める。

入院時検查（表 1 ）：1989 年 11 月 10 日入院時検查で は GOT $459 \mathrm{IU} / l, \mathrm{GPT} 357 \mathrm{IU} / l, \mathrm{LDH}$ 1,669 IU $/ l, \mathrm{CPK}$ $529 \mathrm{IU} / l$ と異常を認め, 透析後でドライウエイト以下の 体重になっていたが, 胸部X線では心陰影の拡大，胸水 の貯留を認めた。

入院経過 (図): 著明な低酸素血症 $\left(\mathrm{PO}_{2} 27.1 \mathrm{mmHg}\right.$, $\mathrm{PCO}_{2} 42.8 \mathrm{mmHg}$ ) があり, 酸素を投与したが, 低酸素 状態は改善しなかった.このため肺梗塞を疑い Swan$\mathrm{Ganz}$ カテーテル挿入し循環動態を測定したが, 明らか な肺梗塞の所見は得られず，むしろ肺水腫の所見を示し た.しかし微小肺梗塞の可能性も否定できず，へパリン 1 万単位/:日の持続投与を開始した。

また心筋梗塞, 心筋炎の鑑別のため, 心エコーを行っ たが，心筋の異常運動等はなかった.

一方, aldolase $13.3 \mathrm{mU} / \mathrm{m} l$, myoglobin $3,200 \mathrm{ng} / \mathrm{m} l$ と異常がみられ，横紋筋融解症が疑われた。さらにメト クロプラミドの服薬歴があり, 発熱と振戦, 筋硬直と意 識障害, CPKの上昇より, 悪性症候群の可能性が強く考

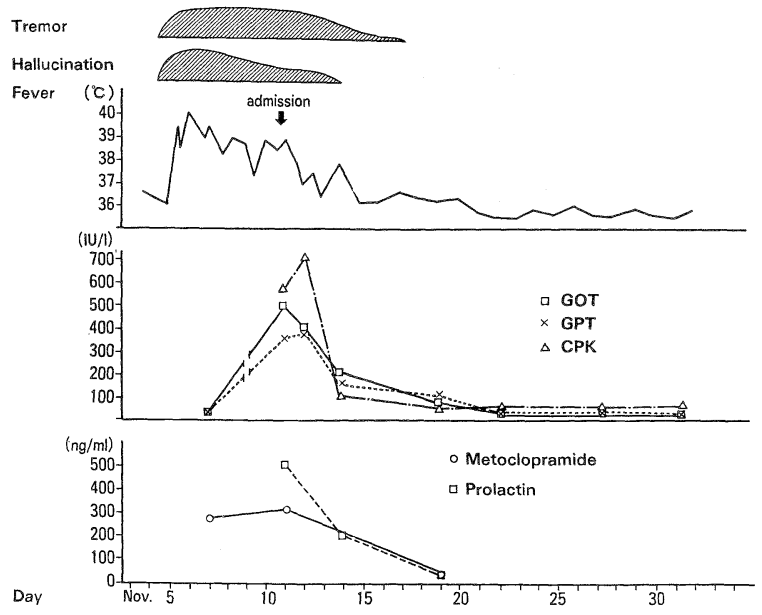

図 Clinical course

えられた(表 2 )。このため内服中の薬剤を中止し, 血糖 のコントロールを厳密に行い,さらに臨時に透析を行い 全身状態を安定させた。この結果, 低酸素, 酵素異常は 改善した。酵素異常の改善とともに解熱, 振戦も消失し た.その後順調に経過し，11月 30 日退院となった。

\section{考察}

悪性症候群 (syndrome malin) は,一般に抗精神病薬の 投与中に, 発熱と共に発汗, 頻脈, 唾液の異常分泌等の自 律神経症状と, 笳硬直, 四肢振戦, 眼振等の錐体外路症状, さらに意識障害を呈する稀な合併症である。重症例で意 識障害が進行し，20～30\%が救命できないといわれてい る.また悪性症候群の誘因となる薬剂は, その投与法, 投与量, 期間に関係なく突然に発症することもある ${ }^{1,2)}$.

悪性症候群の発症機序については明らかではないが, 薬剤によって中枢神経系の脳内ドーパミン系機能が変化 してドーパミン受容体が阻害され, 異常高熱や筋硬直が 出現すると考えられ ${ }^{3)}$, 筋組織の崩壊を起こし, 高 $\mathrm{CPK}$ 
表 2 Other laboratory data

\begin{tabular}{lr|ll}
\hline AT III & $109 \mathrm{mg} / \mathrm{d} l$ & LDHiso & $1,7.8 \% \quad 2,12.9 \% \quad 3,9.9 \%$ \\
APTT & $29 \mathrm{sec}$ & & $4,11.1 \% \quad 5,78.3 \%$ \\
Fiburin & $650 \mathrm{mg} / \mathrm{d} l$ & CPKiso & $1,000 \mathrm{IU} / l \quad \mathrm{MM} \mathrm{98 \%} \quad \mathrm{MB} 2 \%$ \\
FDP & $10 \mathrm{mg} / \mathrm{d} l$ & Aldolase & $13.3 \mathrm{mU} / \mathrm{m} l$ \\
$\beta$-hydroxybutyrate & $68 \mu \mathrm{mol} / l$ & Myoglobin & $3,200 \mathrm{ng} / \mathrm{m} l$ \\
Acetoacetate & $87 \mu \mathrm{mol} / l$ & IgE & $306 \mathrm{IU} / \mathrm{m} l$ \\
Pyruvate & $0.3 \mathrm{mg} / \mathrm{d} l$ & Prolactin & $505 \mathrm{ng} / \mathrm{d} l$ \\
Lactate & $7 \mathrm{mg} / \mathrm{d} l$ & Metoclopramide & $312 \mathrm{ng} / \mathrm{d} l$ \\
& & plasma Osmo & $274 \mathrm{mOsmo} / \mathrm{kg}$ \\
\hline
\end{tabular}

血症, 高 myoglobin 血症を引き起こし, 急性腎不全, 急 泩心不全に至る。さらに個体側の要因として脳の脆弱性 や身体の疲弊状態, 糖尿病, 肝腎疾患が, 誘因となると いわれている。

近年, 制吐剤として頻用される塩酸メトクロプラミド (metoclopramide hydrochloride 分子式 : $\mathrm{C}_{14} \mathrm{H}_{22} \mathrm{ClN}_{3}$ $\mathrm{O}_{2} .2 \mathrm{HCl} . \mathrm{H}_{2} \mathrm{O}$ 分子量：390.74）による同様の合併症も 報告され出している ${ }^{4,5)}$.

今回我々は, 維持透析患者においてメトクロプラミド 内服中に悪性症候群様症状を合併した 1 例を経験したの で報告した。本症例では, 糖尿病性胃腸障害のため約 5 か 月にわたるメトクロプラミドの内服歴があり，一過性に 手指振戦や自発性の低下があったが，重大な副作用は認 められなかった。症状の発症は突然で, 発熱で始まり, 錐体外路症状, 自律神経症状, 意識障害と急激に病状が 進行していった。

健常人ではメトクロプラミドの大半が尿中排泄され る。本例の血清メトクロプラミドは $300 \mathrm{ng} / \mathrm{m} l$ 前後に上 寻しており, 透析の前後で大きな変化がなく, 体内の蓄 䅡が考えられた。

また下垂体ホルモンである血清 prolactin も20 倍近 く上昇し，中枢神経系に対する影響も窅えた ${ }^{6)}$.

本症例では薬剤の中止，血糖の厳密なコントロール， 臨時の透析による全身管理によって病状は回復した。悪 忹症候群に扔いては全身管理のほか, dantrolene

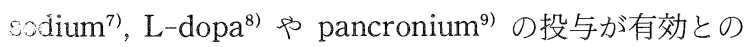
啹告もあるが，使用するのに至らなかった。

本症例は悪性症候群の軽症例なのか, 血液透析が進行 意印えたのかは不明であるが，透析毎に一時的に症状が 緩和されたのは興味深い。一般に横紋筋融解症が血液透 行により予後が良くなるように，本例でも血液透析とい う全身管理が予後を良好にした可能性もある。血液透析 ふメトクロプラミドを除去できないが，myoglobinの除 組織障害を軽減している可能性もあり，さらに水分 管理による肺水腫の改善により，組織の低酸素血症，ア
シドーシスの改善が予後を良好にしたと思われる。

\section{結語}

慢性透析患者に発症したメトクロプラミドによる悪性 症候群症状を合併した 1 例を報告した。長期の経口投与 の後, 突然, 悪性症候群症状を合併することがあり, 糖 尿病合併の透析患者には特に注意が必要である。悪性症 候群症状を合併した時，直ちに薬剤の中止と，透析によ る管理を厳密に行う必要がある。

\section{文献}

1）萩田和宏: Syndrome malin. 精神医学 $22 ： 1229$ 1237, 1980

2）萩田和宏，神定 守：Syndrome malin の予防と治 療。神経精神薬理 5 : 437-443，1983

3) Henderson VW, Wooten GF : Neuroleptic malignant syndrome: A pathogenic role for dopamine receptor blockade. Neurology $31: 132-137,1981$

4) Patterson JF : Neuroleptic malignant syndrome associated with metoclopramide. South Med J $81: 674-675,1988$

5) Lawrence S. Friedman, Larry A. Weinrauch, John A. D'Elia : Metoclopramide-induced neuroleptic malignant syndrome. Arch Intern Med 147 : 1495 -1497, 1987

6) Bateman DN, Clare Kahn, K. Mashiter, Davice DS : Pharmacokinetic and concentration-effect studies with intravenous metoclopramide. $\mathrm{Br} \mathrm{J}$ Pharmacol 6:401-407, 1978

7) Coons DJ : Treatment of neuroleptic malignant syndrome with Dantrolene sodium. Am J Psychiatry $43: 381,1982$

8）新谷周三，林 正高：悪性症候群 2 例の治療経験, 神経内科治療 $1: 319-322,1984$

9）本田 弘，鈴木正典：臭化パンクロニウムを使用し た悪性症候群の 1例. 救急医学 11：1029-1032, 1987 